\title{
CRITERIA AND FACTORS FOR THE CHOICE OF PRIVATE LABEL BRANDS BY CUSTOMERS OF RETAIL CHAINS
}

\author{
Karolina Muszyńska \\ Wroclaw University of Economics and Business, Wroclaw, Poland \\ e-mail: karolina.muszynska@ue.wroc.pl \\ ORCID: 0000-0001-5951-5867 \\ (C) 2019 Karolina Muszyńska \\ This is an open access article distributed under the Creative Commons Attribution-NonCommercial-NoDerivs license \\ (http://creativecommons.org/licenses/by-nc-nd/3.0/) \\ DOI: $10.15611 / \mathrm{ms} .2019 .4 .03$ \\ JEL Classification: M31, M20, L11
}

\begin{abstract}
The primary aim of the paper to determine the criteria and factors applied by customers making decisions about buying private label brands of retail chains. An additional goal is to examine their level of awareness regarding the place of origin and ingredients used in the production of own branded products. The development of private label brands and their functioning on the consumer goods market are discussed. An analysis of the image of private label brands in the eyes of customers was conducted. The research method used is a diagnostic survey carried out via the internet. The adopted research methodology allowed to answer all the questions posed. A review of empirical research results showed that factors influencing purchasing decisions differ between generations and that young people more often use products of private brands, especially groceries, than older people. The article is of a research nature.
\end{abstract}

Keywords: own brands, retail chains, consumer choices.

\section{Introduction}

The needs, choices and motives that guide customers are the main source of knowledge during the creation of an appropriate marketing strategy [Małysa-Kaleta 2016]. The turbulent environment encourages the buyers to look for new ways to satisfy their consumption needs. It also affects entrepreneurs who feel obliged to undertake innovative actions [Mazurkiewicz 2013]. Since the 1980s, retail chains have been developing the private label segment, which has been evolving for years and now also includes premium products [Spyra 2007].

The aim of the paper is to establish the criteria and factors that influence customers choosing private label brands of retail chains. In addition, the perception of the image of private label brands in the eyes of customers and their awareness of manufacturers (origin of the products) was examined.

In order to find solutions for these issues, a literature search and a survey of customers of retail chains in Poland were conducted. As a research method, a diagnostic survey was adopted carried out via the Internet, with respondents selected to ensure representation by age; 294 respondents participated in the study.

\section{Purchasing decisions of modern customers - a literature review}

The main basis for purchasing choices is the value of individual products and services as perceived by the customer [Modrzejewska 2010]. Customers consider the benefits and compare them with the effort and financial and psychological costs they have to incur to buy a product or service. Value assessments are often not accurate or objective. One reason may be the company's image, because when buying a product that enjoys a high reputation and prestige, customers are willing to pay more, thus demonstrating trust in the manufacturer. On the other hand, they approach less well-known and recommended brands with caution, although emerging brands often represent a better quality than the market leaders - it all depends on 
the strategy the individual organization adopts. The perceived benefits associated with own brands are related to the consumer's conviction that thanks to the purchase of the own brand of a given network, they will receive a higher quality product than in the stores of another retailer [Diallo 2012].

The key to success is to match the customer's expectations with the company's capabilities. Top market leaders seek to attract customers by only making promises that they can fulfill, and then striving to exceed consumer expectations. In his work, Philip Kotler presented a systematization of factors influencing purchasing decisions by classifying them into cultural, social, personal and mental ones [Kotler et al. 2002].

The existing literature on the subject provides several definitions of private label brands. The most commonly used definition is to see it as a commercial brand that designates products made by various manufacturers and distributed through the chain of the given retailer who ordered them [Domański 2001, p. 123]. According to Nielsen, a private label is a brand belonging to a retail or wholesale chain, and concerns products which are offered exclusively by these companies and under their control [Lubańska 2011]. A more comprehensive definition range was presented by Lincoln and Thomassen, indicating that a private brand (retailer brand) includes brands whose products are owned by the retailer, sold and distributed by the retailer who makes decisions about the management of a brand and its development [Lincoln, Thomassen 2009]. Retailers systematically improve the quality of own brands, reposition them and increasingly try to build their image not as simple imitations of manufacturer brands, but in a way that ensures their own brands an independent place on the market [Mieres et al. 2006, pp. 61-82].

Private labels have evolved and gained new values. They are usually positioned according to their price, and are divided into the following categories: the cheapest (economy), the medium-price product group with the assertion of the highest product quality (value for money) and the premium product group [Geyskens, Gielens, Gijsbrechts 2010].

The development of private labels has gone through four generations. The first generation of private label brands were basic products in a given product group, in basic packaging, sold at the lowest price. Selected products in the individual categories were arranged on shelves and labelled in such a way as to evoke an association with the lowest retail price as an incentive to buy. The prices were lower than those of brand products by an average of $30 \%-50 \%$. This was due to the use of basic production and packaging technologies and the simplicity of label design. Private label brands were associated with low prices, but also with poor quality.

In the second phase of development, an attempt was made to change the image of the private label brands in terms of the perception of their quality. Retailers started to introduce their own label designs and to control quality, still maintaining the lowest retail price in a given category of goods. These activities were aimed at increasing the profit margin and reducing the strength of suppliers by introducing the cheapest products on the shop shelves. In this phase of development, the main positioning criterion was the price, with private labels providing a background for company brands.

The third generation of brands consists in imitating the product characteristics of the leading product in a group of products, and offering it at a lower price. The quality of the product and its packaging, i.e. its design, weight and shape, are associated by the consumer with the company brand. The imitation strategy was to draw directly on the achievements and ideas of the manufacturer. As a result, the retailers did not have to bear the costs of developing the concept, while at the same time earning profits. The quality was guaranteed by the application on the products of the own logo of the manufacturer, which most often was a specialized company or manufacturer of leading market brands with high technology and the ability to provide adequate volumes of production while maintaining their high quality. The competition between private labels and market leaders became balanced as the former gradually improved their quality, functionality and graphic design.

The fourth generation of private labels began to develop in the first decade of the 21st century. The products began to stand out for their good quality, which was appreciated by customers, on the other hand their prices were kept as low as possible. The variety of products was expanded by product categories sold at higher prices and intended for the premium segment. Retailers focused on building a positive image, increasing customer loyalty and distinguishing themselves on the market by creating a unique offer of niche products available only at their points of sale [Nowak, Śmigielska 2013, pp. 11-13].

Consumer reservations about the quality of private label products stemmed to a large extent from a certain negligence on the part of retail chains when launching the products on the market, consisting in the lack of reliable market research, a focus on the price alone, and the failure to take into account customer expectations regarding the quality of products and the aesthetic qualities of their packaging [Pindakiewicz 
2007]. Horvat and Ozretić-Došen [2015, p. 60] indicate that retail chains are currently investing in improving the quality of these products because they are not only the goods on the shelf, but also a certificate of the quality of the commercial network brand in the eyes of consumers.

Nowadays, over $40 \%$ of buyers are convinced that private label products are of at least the same quality, if not better, compared to those produced under the manufacturer's brands. Moreover, customers are willing to pay the same or even higher prices for private label products [Pindakiewicz 2007].

The effects of retailers' activities are illustrated by Nielsen's 2017 statistics available on the website of the Private Label Manufacturers' Associacion (PLMA) [Nielsen 2017], which show that the market share of private labels in nine European countries has now risen to its highest level. In 15 of the 20 countries the PLMA has tracked, for the first time in history the threshold of $30 \%$ and more has been reached. The best results in this category were achieved in Germany, Italy, the Netherlands, Belgium, Austria, Sweden, Norway, Denmark and Poland.

In $2018,10 \%$ of all new private label products in the world were premium private labels, with European countries accounting for the largest share in this segment [Wiadomości Handlowe 2019]. Ethnocentrism is gaining popularity among customers, therefore detailed information on the origin of private label products is an additional asset. Over $60 \%$ of customers in Poland are willing to buy private labels if, by doing so, they can support small local businesses [Wiadomości Handlowe 2019].

Private label brands account for $40 \%$, and even up to $70 \%$ of the products sold by discount stores [Orlikowski 2019]. Their growing popularity has become a cause for concern for domestic manufacturers and farmers. At the European Agricultural Forum in Jasionka in March 2019, it was announced that they wanted to prepare a law that would limit the sale of private labels in discount stores [Orlikowski 2019]. The date of implementation of the law is not yet known.

\section{The aim and the method of research}

The main aim of the research was to determine which criteria and factors influence consumer choices when buying private label brands of retail chains. An additional objective was to examine the perception of the image of private label brands by the customers. The study was of a pilot nature, used to indicate the possibility of further research.
The research method a diagnostic survey was adopted, carried out via the Internet with respondents selected of respondents shopping in retail chains in Poland and aged $18-24 ; 25-30 ; 31-39 ; 40-49 ; 50-59$ and 60-69. The applied research tool was a specially prepared questionnaire consisting of 22 closed questions. The questionnaire was created in docs.google and then published on numerous Internet forums. The survey took place between 05.2018-09.2019, and 294 respondents participated in the study. The adopted research methodology allowed for answering all the posed questions.

\section{Main question:}

What are the criteria and factors influencing customers' choice of private labels?

\section{Specific questions:}

1. What characteristics do customers attribute to private labels?

2. Does age influence customers' choice of private labels?

3. Does education influence customers' choice of private labels?

4. Does monthly income influence customers' choice of private labels?

5. Does the place of residence influence customers' choice of private labels?

\section{The results research and discussion}

Among the 294 customers surveyed, (71\%) were women, a significant proportion of whom, i.e. $56.8 \%$ in the age range of $21-29$, and $57.6 \%$ live in a city of more than 500,000 inhabitants. The highest number of respondents declared having secondary/ technical education $(39.1 \%)$, followed by tertiary education (31\%) and incomplete tertiary/engineering education (29.7\%). $48.4 \%$ of the respondents thought that their level of income was medium, 1,500-2,499 PLN, $26.5 \%$ as high, 2,500-4,499 PLN, $17.7 \%$ as low, 1,000-1,499 PLN and 7.5\% declared very high income, above 4,499 PLN.

Thirty-one women and twelve men took part in the follow-up studies, which translates into $10 \%$, $5 \%$ and $4.1 \%$ of the total sample. Among them, 28 respondents are in the age range of 50-59 years. In the second round of research, $70 \%$ of the participants were inhabitants of cities over 500,000 residents. The respondents aged 60-69 declared PLN 1500-2499 as their income level.

As can be seen in Figure 1, in the case of the factors influencing the decision to purchase a given product, the most important ones are the price $(95.2 \%)$ and the quality $(88 \%)$. The third answer was 
the manufacturer's/supplier's brand (41.8\%). The less important criteria are: a recommendation by a friend (20.6\%), the appearance of the packaging $(6.8 \%)$ and labelling the product with a certificate $(5.8 \%)$. The impact of advertising on purchasing decisions is estimated at $5.1 \%$.

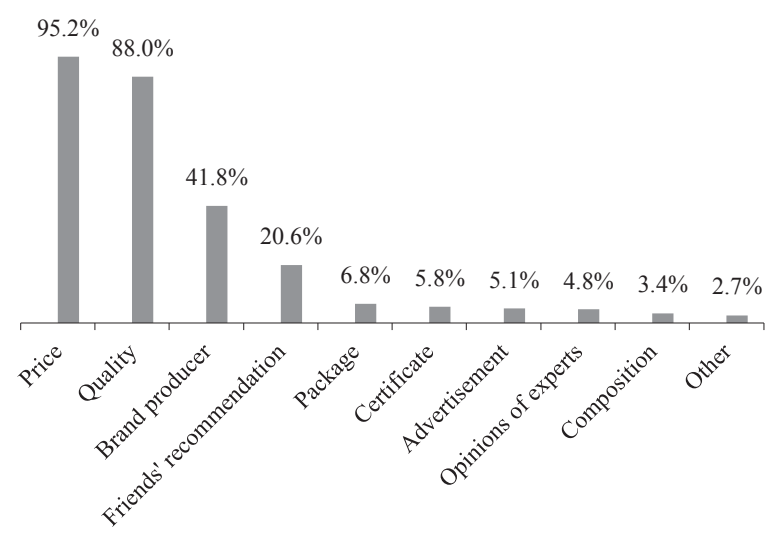

Fig. 1. General factors influence your purchasing decisions. $\mathrm{N}=294$

Source: own study.

Figure 2 shows that the most frequently chosen category of private labels of retail chains is food (73.5\%), followed by hygiene products such as toilet paper, cosmetic pads (25.5\%) and household articles $(7.8 \%)$. The least frequently purchased products are children's items $(3.0 \%)$, cosmetics and pet food $(2.4 \%)$.

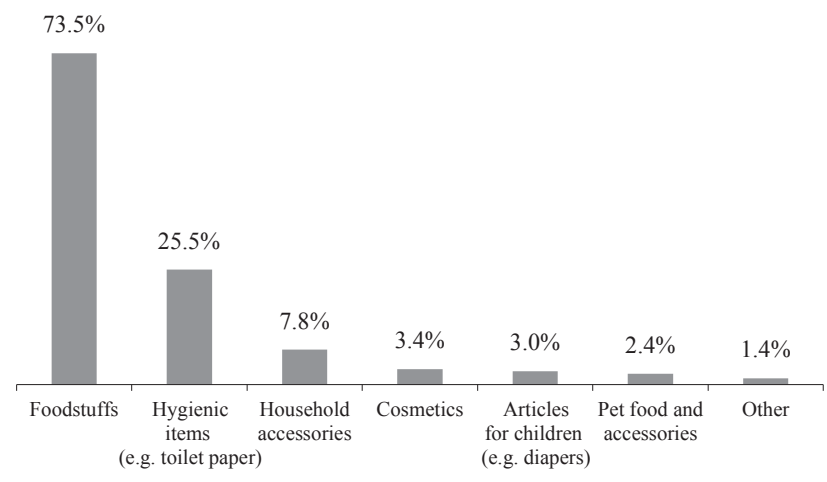

Fig. 2. What is the category which most often buys private label products from retail chains. $\mathrm{N}=294$

Source: own study.

Moreover, respondents were asked to mark which category of products they buy if they have the choice between a private label product vs brand product (by a manufacturer who at the same time offers private label products). In the categories of products associated directly with a given producer, the respondents were not interested in their private label $(85 \%)$. On the other hand, in the reports where there is high competition on the market, consumers more often reach for own brand $(60 \%)$.

Private labels are mostly associated with low price $(47.3 \%)$ and are seen as an alternative to the established brands (20.7\%). The combination of low price and high quality is coherent for $9.9 \%$ of the respondents, and roughly the same number of respondents is inclined to categorize retail chains' products as discount products. According to the respondents, private labels are more often associated with poor $(7.7 \%)$ than with good quality $(6.1 \%)$. The responses are presented in Figure 3.

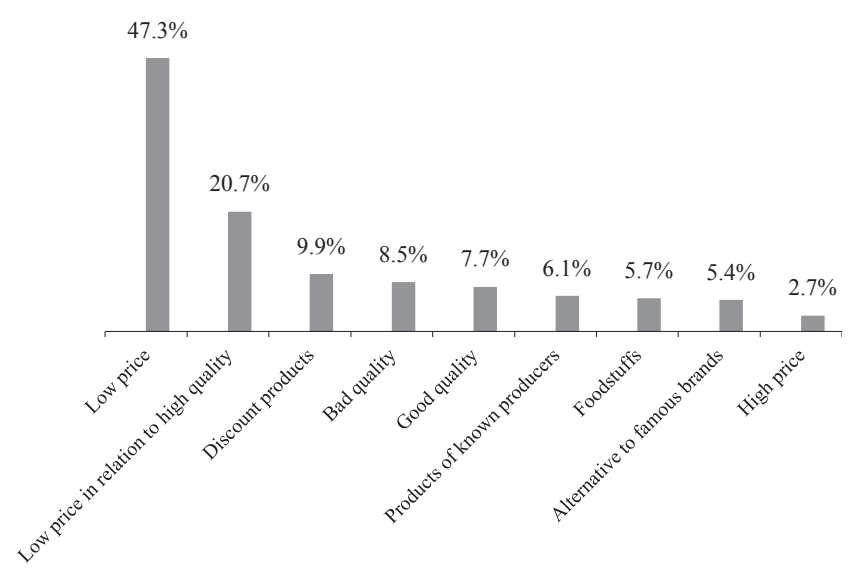

Fig. 3. Associations connects own brands. $N=294$

Source: own study.

Figure 4 shows that, in the opinion of the respondents, in order to improve the image of the retail chains' private label brands, the quality of the products $(45.9 \%)$ and the appearance of the packaging $(34.7 \%)$ should be improved, and the variety of products $(22.1 \%)$ should be increased.

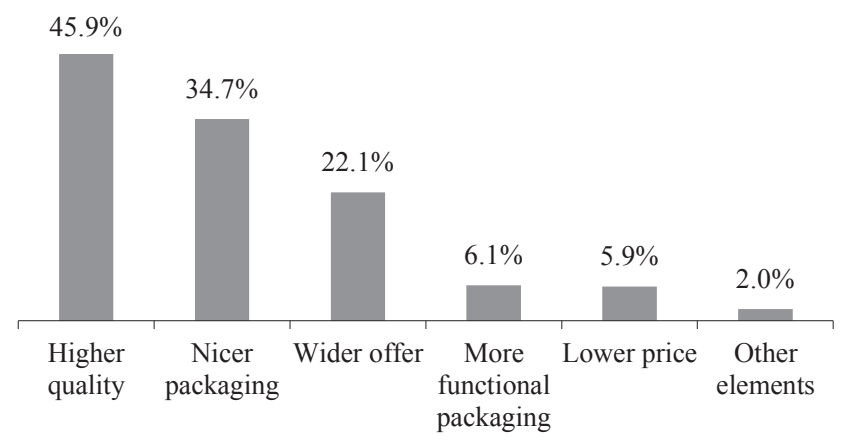

Fig. 4. What can be changed in private labels to improve their image in the eyes of consumers and encourage more purchases? $\mathrm{N}=294$

Source: own study.

People in the 21-29 age range are positive about their own brands and are aware of their origin. On the other hand, older customers who remember the 
beginnings of private labels' entry onto the market approach them with caution and choose what they are familiar with. Over half of the respondents declare that they pay attention to the brand of the product they are buying, while advertising has no impact on their consumer decisions. The justifications for seeking information and knowledge that private label producers are leading brands on the market can be found in the growing consumer awareness among the public.

The average income of respondents oscillates between the average range, PLN 1500-2499 and the high one, PLN 2500-4499, and the vast majority of respondents are attracted to low prices. It follows that the level of income does not correlate with the purchase of private labels.

However, it should be noted that consumers do not always declare their choices truthfully. Urszula Garczarek-Bąk conducted a consumer survey using virtual ethnography, which showed a significant discrepancy between the respondents' responses in the study and the actual number of own-brand products they bought. In $85 \%$ of submitted declarations, inaccuracies were observed regarding individual product categories; usually consumers did not admit having certain products [Garczarek-Bąk 2016].

\section{Conclusion}

The basis for the purchasing decisions of customers is the perceived value of individual products and services. For over a dozen of years, discount chains have consistently increased their market share, and, together with hypermarket chains, they now rank among the top ten of the largest market players. The main product strategy for them is the distribution of private label brands, which have evolved over the years. They used to be perceived as products of lower quality - but nowadays steps are still being taken to improve their image by changing the layout of packaging, changing the composition of the products, following nutritional trends, or introducing local and dietary specialties and premium brands.

As the results of the survey show, buyers are guided by price and quality when deciding whether to buy a product or not, and they are also aware of the origin of private label brands and perceive them as high quality products at low prices. In order to meet the expectations of customers, the already broad portfolio of private labels in retail chains is growing year by year.

Answers were given to the research questions raised, and the main research goal was achieved.

\section{Bibliography}

Diallo M.F. (2012), Effects of store image and store brand price-image on store brand purchase intention: Application to an emerging market, Journal of Retailing and Consumer Services, no. 19(3).

Domański, T. (2001), Strategie marketingowe dużych sieci handlowych, Wyd. Naukowe PWN, Warszawa-Łódź.

Garczarek-Bąk U. (2016), Różnice pomiędzy deklaracjami dotyczacymi zakupu produktów marek wtasnych sieci handlowych a faktycznymi decyzjami młodych nabywców, Uniwersytet Ekonomiczny w Poznaniu, Poznań.

Geyskens I., Gielens K., Gijsbrechts E. (2010), Proliferating private-label portfolios: how introducing economy and premium private labels influences brand choice, Journal of Marketing Research, no. 47, October.

Gruszczyński L.A. (2003), Kwestionariusze w socjologii: budowa narzędzi do badań surveyowych, Wydawnictwo Uniwersytetu Śląskiego, Katowice.

Horvat S., Ozretić-Došen Đ. (2015), Implementation of the product life cycle concept in private label management: focus on the growth stage, [in:] Martinez-López F.J., Carlos Gázquez-Abad J., Sethuraman R. (eds), Advances in National Brand and Private Label Marketing, Second International Conference, Springer International Publishing, Switzerland.

Kotler P., Amstrong G., Saunders, v. Wong J. (2002), Marketing. Podręcznik Europejski, Polskie Wydawnictwo Ekonomiczne, Warszawa.

Lincoln K., Thomassen L. (2009), Marka prywatna. Jak przekształcić zagrożenia $w$ szanse dla detalisty $i$ producenta, Wolters Kluwer, Kraków.

Lubańska A. (2011), Znaczenie marek własnych sieci handlowych $w$ Polsce, Wyd. SGGW Warszawa.

Małysa-Kaleta A. (2016), Misja konsumenta we wspótczesnym świecie, Handel Wewnętrzny, wyd. 4.

Mazurkiewicz P. (2013), Czas na innowacje w handlu [online], Rzeczpospolita Polska (15.08.2019). Available on the Internet: https://www.rp.pl/artykul/1004559-Czas-na-innowacjew-handlu.html.

Mieres C., Martín A.M.D., Díaz Gutiérrez A.M., Trespalacios J.A. (2006), Antecedents of the difference in perceived risk between store brands and national brands, European Journal of Marketing.

Modrzejewska K. (2010), Zachowanie zakupowe klientów w handlu elektronicznym, Uniwersytet Ekonomiczny w Poznaniu, Poznań.

Nowak M., Śmigielska G. (2013). Ewolucja marki własnej na rynku FMCG w Polsce, PWE, Kraków.

Orlikowski P. (2019), Rzad znów zabiera sie za sieci handlowe. „Utrudnimy im sprzedaż własnych marek” [online], Money (20.08.2019). Available on the Internet: https:// www.money.pl/gospodarka/rzad-znow-zabiera-sie-za-siecihandlowe-utrudnimy-im-sprzedaz-wlasnych-marek-6355 080444372609a.html.

Pindakiewicz J. (2007), Marki dystrybutorów w tworzeniu wartości dla klientów, [in:] J. Szumilak (red.), Rola handlu w tworzeniu wartości dla klienta, Fundacja UE w Krakowie Kraków.

Spyra Z. (2007), Kanat dystrybucji: ksztattowanie relacji, CeDeWu, Warszawa.

Wiadomości Handlowe (2019), KRFMCG: Marki własne kreuja nowy styl życia (20.08.2019). Available on the Internet: https://www.wiadomoscihandlowe.pl/artykuly/krfmcg-marki-wlasne-kreuja-nowy-styl-zycia,54792.

www. Nielsen.com [Access: 22.08.2018]. 


\section{KRYTERIA I CZYNNIKI WYBORU MAREK WLASNYCH SIECI HANDLOWYCH PRZEZ KONSUMENTÓW}

Streszczenie: Głównym celem pracy jest wskazanie, jakie kryteria i czynniki wpływają na konsumentów wybierających marki własne sieci handlowych. Dodatkowym celem jest zbadanie ich poziomu świadomości dotyczącej miejsca pochodzenia i składników wykorzystanych w produkcji wyrobów sygnowanych markami własnymi. Podjęto kwestie rozwoju marek własnych i ich funkcjonowania na rynku dóbr. Została dokonana analiza wizerunku marek własnych w oczach konsumentów. Wykorzystana metoda badawcza to sondaż diagnostyczny przeprowadzony za pośrednictwem Internetu, co pozwoliło na uzyskanie odpowiedzi na postawione pytania badawcze i zrealizowanie celu głównego badań. Analiza wyników badań empirycznych wykazała, że czynniki wpływające na decyzje zakupowe różnią się między pokoleniami oraz że generacja Y częściej sięga po produkty marek własnych, szczególnie artykuły spożywcze, niż osoby starsze. Artykuł ma charakter badawczy.

Słowa kluczowe: marki własne, sieci handlowe, wybory konsumenckie. 